\title{
Parametric Meta-Technology Frameworks to Study Technical Efficiency and Macro-Economic Effects in the European Banking System
}

Bilel Jarraya ${ }^{1}$

\begin{abstract}
Bank efficiency scores usually serve as a tool for comparing institutions with each other while allowing us to quantify sub-optimal decision-making unit choices. In the case of inter-country comparisons, such differences can also arise because of macro-economic heterogeneity between countries. Previous studies estimated a common technology limit for a sample of banking institutions in different countries. The contribution of our paper is that we employ a parametric approach to specify metafrontiers and to study the effect of macro-economic heterogeneity on banking technology development. First, we use a parametric directional distance function to specify the appropriate technology frontier for each nation and the meta-technology frontier that includes all country-specific frontiers. Then, we define the directional technology gap ratio referring to the inefficiency scores evaluated from meta-technology and country-specific technology frontiers. The estimated parameters are more significant in our model than in the general model, also called the common frontier model. Comparing the results of our model to those of common frontiers, we find a substantial variation not only in inefficiency scores but also in countries' rankings. While resorting to a pooled linear regression model, we demonstrate that the assessed technology gap ratio exhibits a significant association with inflation rates and per capita GDP. This result proves the influence of macro-economic heterogeneity on banks' efficiency and technological development.
\end{abstract}

KEY WORDS: $\quad$ directional meta-technology; directional technology-gap ratio; directional distance functions; banking efficiency; macroeconomic heterogeneity

JEL Classification: G21, F62, F65

${ }^{1}$ FSEG Sfax - FINANCE Sfax, Tunisia

\section{Introduction}

The banking sector has basic responsibilities in any economy. It keeps the savings of different economic agents and finances business and trade projects in

$\square$

Correspondence concerning this article should be addressed to: Bilel Jarraya, FSEG Sfax - FINANCE Sfax, road gremda km7 Sfax 3048 Tunisia. E-mail: bilel.jarraya@gmail.com all sectors. Moreover, several researchers have demonstrated that the efficiency of financial institutions has a significant effect on economic growth, whereas others confirmed that bank insolvencies could be a result of economic crises, which has undesirable consequences for the whole economy. As a consequence, banks' performances are an interesting issue for diverse stakeholders, such as investors, customers, regulators, and the general public. 
Several studies that were designed to find a benchmark for banks in different countries were based on the hypothesis that these banks actually do have a common efficiency frontier. This hypothesis appears to be trivial. However, this assumption is actually strong, especially in the event of a cross-country comparison, for many reasons. In the benchmark studies, the researchers were mostly interested in banks that were the furthest from the benchmark frontier. These banks in particular may not share this common frontier. First, this could just reflect poor performance. Second, they could be too heterogeneous for comparison with a common technology; thus, we must account for heterogeneity appropriately in defining technology frontiers. Consequently, the problems of how to identify benchmarks and how to consider macro-economic divergences are crucial because this heterogeneity influences efficiency estimates substantially.

The remainder of this paper is organized as follows: The next section is a literature review of different studies that demonstrate the influence of environmental and macroeconomic divergences on banks' technology. Section three describes our methodology, while section four presents the theoretical and empirical implications. Concluding remarks are made in the final section.

\section{Literature review}

Banks represent the heart of any economy; for this reason, research studies are increasingly directed towards this sector (Hachicha \& Jarraya, 2010; Jackowicz \& Kowalewski, 2011; Jackowicz, Kowalewski \& Kozłowski, 2011; Stefański, 2009). Several research methods can be employed for studying the banking sector. Bank performance studies and, in particular, efficiency studies of these financial institutions are among the most important methods (Berg, Førsund, \& Jansen, 1992; Berger \& Humphrey, 1991; Berger \& Mester, 1997; Chang, Hasan \& Hunter, 1998; DeYoung \& Nolle, 1996; Dietsch \& Lozano-Vivas, 2000; Lozano-Vivas, Pastor \& Hasan, 2001; Mahajan, Rangan \& Zardkoohi, 1996; McAllister \& McManus, 1993; Mester, 1996; Peek, Rosengren \& Kasirye, 1999; Qinyu et al., 1997). During the last decade, there has been an increase in empirical studies that estimate common frontiers for assessing and comparing bank inefficiencies between countries. However, judgments regarding inefficiencies referring to common frontiers are biased because each country has its own macroeconomic characteristics. Bank technology frontiers might necessarily be related to macroeconomic movements, such as inflation rates, monetary policy, and interest rate changes, etc. Such macroeconomic movements influence the economy as a whole and the banking sector in particular. The response and the sensitivity to these changes differ from one institution to another. Thus, these economic forces necessarily affect banks' efficiency and technological development. Consequently banks are influenced by regional economic conditions, so we cannot refer to a common frontier to compare bank inefficiency scores between countries (Bikker, 2002; Dietsch \& Lozano-Vivas, 2000; Orea \& Kumbhakar, 2004). Since the emergence of the X-efficiency notion with the work of Leibenstein (1966), several studies have focused on cross-country comparison of bank inefficiency (Allen \& Rai, 1996; Berg et al.,1993; Pastor, Pérez \& Quesada, 1997; Vander Vennet, 1994; Zago \& Dongili, 2011). The relevant literature emphasizes the role of various exogenous factors in banking efficiency (Bottasso \& Sembenelli, 2004; Hachicha \& Jarraya, 2010; Pasiouras, 2008). So, to neglect environmental and macroeconomic heterogeneity between countries might lead to misleading and biased results (Berger et al.,2000; Chaffai, Dietsch \& Lozano-Vivas, 2001; Dietsch \& Lozano-Vivas, 2000; Khan and Senhadji, 2000; Lozano-Vivas et al., 2001; Lozano-Vivas, J. T. Pastor, \& J. M. Pastor, 2002). For this reason subsequent studies have incorporated country-specific environmental and macroeconomic conditions (Demirguc-Kunt, Laeven \& Levine, 2004; Maudos et al., 2002; Yildirim and Philippatos, 2007). Summarizing these studies, we must agree with Khan and Senhadji (2000), who in providing a review of the literature and empirical evidence of the relationship between financial development and economic growth, concluded that the results indicate that while the general effects of financial development on the outputs are positive, the size of these effects vary with the different variables considered, with indicators of financial development, and with the estimation method, the data frequency or the defined functional form of the relationship.

Therefore, overall macroeconomic conditions should affect bank efficiency. Qinyu et al. (1997) considered several reasons why cost-inefficient banks 

Where $x \in \mathfrak{R}_{+}^{N}$ denotes the input vector, while $y \in \mathfrak{R}_{+}^{N}$ denotes the output vector for each bank.

Hayami and Ruttan (1971) defined the metaproduction function as the envelope of commonly conceived production functions. Referring to this definition, Battese et al. (2004) and Battese and Rao (2002) defined the meta-technology concept $T^{*}$ as an over-arching technology, which envelops the technology of each region. The meta-technology function can be presented as follows:

$T^{*} \equiv\left\{(x, y): x \in \mathfrak{R}_{+}^{N}, y \in \mathfrak{R}_{+}^{M} ; x\right.$ can produce $y$

at least in one country technology $\left.T^{k}\right\}$

The meta-technology can also be expressed as follows:

$T^{*} \equiv$ Convex Hull $\left\{T^{1} \cup T^{2} \cup \ldots \cup T^{K}\right\}$

The technology $\mathrm{T}$ can be completely characterized by the directional technology distance function originally introduced by Chambers et al. (1996). This function allows banks to obtain the optimal composition of inputs and outputs by simultaneously searching the maxima of expansion and contraction of inputs and outputs, respectively. It is generally expressed as:

$\vec{D}_{T^{k}}\left(x, y ; g_{x} g_{y}\right)=\max \left\{\beta^{k}:\left(x-\beta^{k} g_{x}, y+\beta^{k} g_{y}\right) \in T^{k}\right\}$

where $\beta^{k}$ provides the distance between an observation $(x, y)$ and a point on the technology frontier defined for the country $k$, while $g=\left(g_{x}, g_{y}\right)$ is a directional vector, with $g_{x} \in \mathfrak{R}_{+}^{N}$ and $g_{y} \in \mathfrak{R}_{+}^{M}$ establishing the direction in which technical efficiency is measured. It is generally assumed that $\left(g_{x}, g_{y}\right)=(1,1)$. In the case where $\vec{D}\left(x, y ; g_{x} g_{y}\right)=0$, a bank is considered technically efficient, whereas if $\vec{D}\left(x, y ; g_{x} g_{y}\right)>0$, a bank is assumed to be technically inefficient.

Indeed, as we have defined the meta-technology $T^{*}$ above, we conceptualize the directional meta-technology distance function $\vec{D}_{T^{*}}\left(x, y ; g_{x} g_{y}\right)$, which is assumed to be an envelope function of the directional technology distance functions of the different countries and can be expressed as follows:

$\vec{D}_{T^{*}}\left(x, y ; g_{x} g_{y}\right)=\max \left\{\beta^{*}:\left(x-\beta^{*} g_{x}, y+\beta^{*} g_{y}\right) \in T^{*}\right\}$
For a given country $k$, and as a result of the meta-technology definition, we have the following:

$\vec{D}_{T^{*}}\left(x, y ; g_{x} g_{y}\right) \geq \vec{D}_{T^{k}}\left(x, y ; g_{x} g_{y}\right)$

We parameterize the directional distance function as Färe et al. (2005), Hachicha and Jarraya (2010) and Jarraya and Bouri (2013) did, and we opt for a quadratic flexible functional form that must satisfy the restrictions imposed by the translation property and restrictions for symmetry. Thus, the directional distance function is parameterized as follows:

$\vec{D}\left(x, y ; g_{x}, g_{y}, t, \theta\right)=\alpha_{0}+\sum_{n=1}^{N} \alpha_{n} x_{n}+\sum_{m=1}^{M} \beta_{m} y_{m}+$

$+1 / 2 \sum_{n=1}^{N} \sum_{n^{\prime}=1}^{N} \alpha_{n}, x_{n} x_{n^{\prime}}+1 / 2 \sum_{m=1}^{M} \sum_{m^{\prime}=1}^{M} \beta_{m}, y_{m} y_{m^{\prime}}+$

$+\sum^{N} \sum^{M} \gamma_{m} y_{m} x_{n}+\delta_{1} t+1 / 2 \delta_{2} t^{2}+\sum^{N} \psi_{n} t x_{n}+\sum^{M} \eta_{m} t y_{m}$

Usual symmetric restrictions

$\alpha_{n n^{\prime}}=\alpha_{n^{\prime} n} \quad n \neq n^{\prime}$

$\beta_{m m^{\prime}}=\beta_{m^{\prime} m} \quad m \neq m^{\prime}$

Restrictions imposed by the translation property

$\sum_{m=1}^{M} \beta_{m} g_{y}-\sum_{n=1}^{N} \alpha_{n} g_{x}=-1$

$\sum_{n=1}^{N} \gamma_{m} g_{y}-\sum_{m^{\prime}=1}^{M} \alpha_{n} g_{x^{\prime}}=0$

$\sum_{m^{\prime}=1}^{M} \beta_{m} g_{y^{\prime}}-\sum_{n=1}^{N} \gamma_{m} g_{x}=0$

$\sum_{m=1}^{M} \eta_{m}-\sum_{n=1}^{N} \psi_{n}=0$

where $\theta=(\alpha, \beta, \gamma, \delta, \eta, \psi)$ is the parameter vector to be estimated whereas $\varepsilon \stackrel{\text { iid }}{\mapsto} N\left(0, \sigma_{\varepsilon}^{2}\right)$ presents the random error term, and the trend variable explains technical progress.

In the first step, we must estimate the parameters of the frontier $\theta^{k}=\left(\alpha^{k}, \beta^{k}, \gamma^{k}, \delta^{k}, \eta^{k}, \psi^{k}\right)$ of each country $k$ by using a deterministic linear programming procedure proposed by Aigner and Chu (1968). It has also been used recently by Fukuyama and Weber (2008) to estimate inefficiency and the shadow price of Japanese banks.

In a second step, using MATLAB software, we estimate the parameters of the meta-frontier 
$\theta^{*}=\left(\alpha^{*}, \beta^{*}, \gamma^{*}, \delta^{*}, \eta^{*}, \psi^{*}\right)$ that envelopes the estimated stochastic frontiers for the different countries.

In the third and final step, we estimate the directional technology gap ratio for each country. This index allows us to classify countries that have banks that are more efficient than others.

Battese et al. (2004) introduced the notion of the technology gap ratio in cases of output distance function and input distance function. In this paper, we will develop this concept in the case of a directional distance function, and it will be called the directional technology gap ratio.

The directional technical efficiency of each country of an observed input-output combination is defined as follows:

$$
\operatorname{DTE}^{k}(x, y)=\vec{D}_{T^{k}}\left(x, y ; g_{x} g_{y}\right)
$$

The directional technology gap ratio can be defined using the directional technology distance function from technologies $T^{k}$ and $T^{*}$ as follows:

$\operatorname{DTGR}^{k}(x, y)=\frac{\vec{D}_{T^{*}}\left(x, y ; g_{x} g_{y}\right)}{\vec{D}_{T^{k}}\left(x, y ; g_{x} g_{y}\right)}$

Using the definition of directional technical efficiency, the directional technology gap ratio can be defined as follows:

$\operatorname{DTGR}^{k}(x, y)=\frac{\operatorname{DTE}^{*}(x, y)}{\operatorname{DTE}^{k}(x, y)}$

A new decomposition of the directional technical efficiency for an observed pair ( $\mathrm{x}, \mathrm{y})$ can be assessed at the meta-technology.

$$
\operatorname{DTE}^{*}(x, y)=\operatorname{DTE}^{k}(x, y) * \operatorname{DTGR}^{k}(x, y)
$$

This equation shows that directional technical efficiency measured while referring to the meta-technology can be decomposed into the product of the directional technology efficiency assessed with reference to the country-specific technology " $k$ " and the directional technology gap ratio between the country-specific technology " $k$ " and the meta-technology.

The directional technology gap ratio developed above is an indicator of the distance between the directional technology frontier of the country-k and the directional meta-technology frontier. Indeed, we sug- gest that when the average of the directional technology gap ratio calculated for a country-k is the smallest such value, then this country is classified as technically more developed than other countries because its technology is assumed to be nearest to the meta-technology frontier.

To improve the effect of the macroeconomic divergences between European countries on the development of the banking sector, we model the directional technology gap ratio as a linear function of a set of exogenous factors presented by the macroeconomic variables. Due to our data structure, we opt for a panel linear regression. The time-invariant specific-country part of the error term is correlated with the explanatory macroeconomic variables. Likewise, while basing our approach on the Hausman test, we choose fixed effects regression rather than random effects regression because in our case the use of random effects regression provides biased results. The model is depicted as follows:

$\operatorname{DTGR}^{k}(x, y)=\zeta_{0}+\zeta_{i} Z_{i t}+\vartheta_{i t}$

where $\zeta_{0}$ is the specific-country effect, $Z_{i t}$ is a vector of observed exogenous factors that are assumed to influence the directional technology gap ratio, $\zeta_{i}$ is a vector of parameters to be estimated and $\vartheta_{i t} \mapsto{ }_{i i d} \mapsto N\left(0, \sigma_{\vartheta_{t}}^{2}\right)$ is an error term.

\section{Meta-frontier graph}

From figure 1, in a two-dimensional plan of one input, one output, $\boldsymbol{T}^{*}$ presents the meta-technology frontier, $\left\{T^{1}, T^{2} \ldots T^{k}\right\}$ where $T^{k}$ designates the technology frontier of the country $\mathrm{k}$, and $\left(-g_{x}, g_{y}\right)=(-1,1)$ is the directional vector.

Looking at the case of the frontier $T^{1}$ in figure 1 , the vectors' distance $\overrightarrow{A B}$ and $\overrightarrow{A C}$ i ndicate, respectively, $\vec{D}_{T^{1}}\left(x, y ; g_{x} g_{y}\right)$ and $\vec{D}_{T^{*}}\left(x, y ; g_{x} g_{y}\right)$. Whereas the difference between the two vectors $\overrightarrow{A C}-\overrightarrow{A B}$ gives the vector distance $\overrightarrow{B C}$, this vector indicates the distance between the technology frontier $T^{1}$, of country 1 , and the meta-technology frontier. We can explain this example as follows: to operate efficiently, bank $A(x, y)$ must reduce its input by the amount $\beta^{1}$ and increase its output by the same amount $\beta^{1}$. It will then be located at the point $B\left(x-\beta^{1}, y+\beta^{1}\right)$. Thus, this bank becomes domestically efficient, but not internationally 


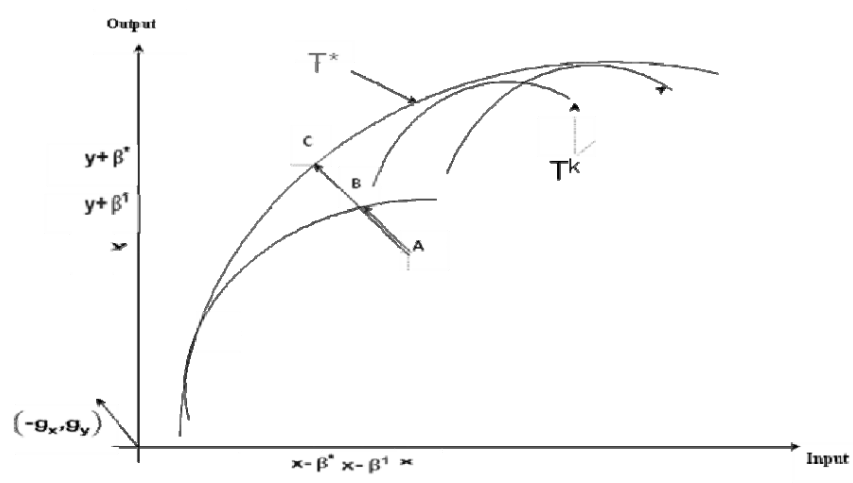

Figure 1. The directional meta-technology distance function

efficient. Indeed, to be internationally efficient, this bank $A(x, y)$ must reduce its input by the amount $\beta^{*}$ and increase its output by the same amount $\beta^{*}$.

\section{Empirical Applications}

\section{Dataset and variables definition}

Having defined the methodological approach to be followed, we focus on the selection and measurement of variables. Referring to a list of European banks by country published by the European Central Bank, we construct a balanced sample of 146 banks operating in ten European countries over the period 2002-2007. All bank data were manually collected from bank accounting information and annual reports. The macroeconomic variables are collected from the International Financial Statistics Yearbook published by the International Monetary Fund. To be included in our sample, each bank must have all variables defined for our model observable for at least four years.

\section{Input output definition}

To apply our model empirically, we must specify first that inputs and outputs are used in the production process. As banks are special types of firms, it is not easy to define our set-put. Indeed, in the literature, two principal approaches can be followed: the production approach and the intermediation approach. The first is described as the value added approach proposed by Berger and Humphrey (1992). This approach is fa- vored if branch level efficiency is calculated to investigate a bank's operational efficiency. However, in the second approach, the bank must, as a principal task, transform the maturity profiles and risks of received funds into a loan portfolio or investment of a different maturity profile and risk by using capital and labor.

In this paper, we opt for the second approach to define the set-put variables used in our study because this approach is more adequate for our banks' environment. Following Sealey and Lindley (1977), the pioneers of the intermediation approach, we specify three outputs: interbank loans, commercial loans and securities. To produce these outputs, we assume that each bank uses three inputs: fixed assets as a proxy of physical capital, personnel expenses as a measure of labor and borrowed funds.

\section{Macro-economic variables}

As in several previous studies, to control countries' macroeconomic conditions, we used the annual GDP per capita and the annual inflation rate (Hauner, 2005; Kasman \& Yildirim, 2006; Maudos et al., 2002; Pastor \& Serrano, 2005). According to Yildirim and Philippatos (2007), suitable economic conditions have a positive effect on the demand of supplied banking services, and this can improve banks' efficiency. Maudos et al. (2002) used the real growth rate of GDP as a proxy for market expansion. The authors demonstrated that, in an expanding market, banks achieve higher levels of profit efficiency, but they can be less efficient regarding 


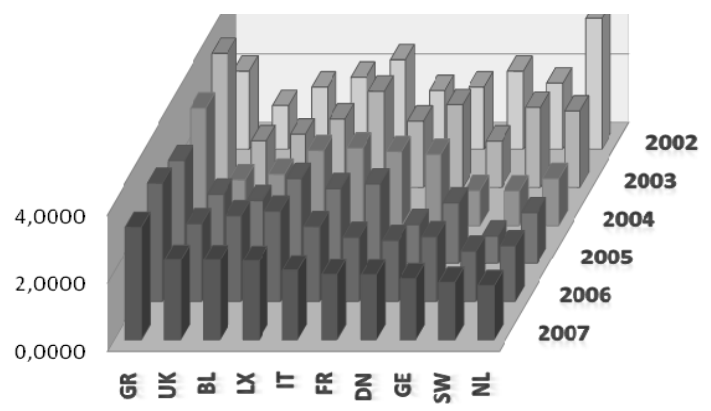

Figure 2. Inflation rate by country

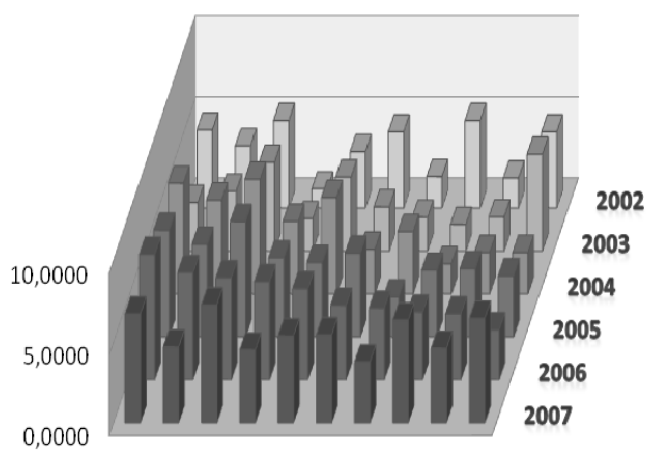

Figure 3. GDP per capita by country

their costs. Yet, Kasman and Yildirim (2006) proved that in an economy characterized by a high growth rate, banking costs are lower. Additionally, the authors demonstrated that a higher inflation rate stimulates competition between banks. Boyd, Levine and Smith (2001) agreed that high inflation rates have a negative effect on financial systems and especially on banks. However, Demirguc-Kunt et al. (2004) suggested that a high inflation rate has a meaningful, positive impact on banking margins and decreases bank costs.

\section{Inflation rate (INFR)}

The annual inflation rate measures the overall percentage increase in the consumer price index for all goods and services. The People's Bank of China uses interest rates to target inflation. They are increased if inflation is expected to rise, to reduce expenditure and borrow- ing by firms and households, which could raise default rates. Both will affect a bank's performance adversely. Following figure 4, the U.K. had a lower inflation rate in 2002 (1.274), although the Netherlands recorded a higher rate (3.826) for the same year. However, in 2007 Greece recorded a higher inflation rate (3.313) when compared to the Netherlands, whose inflation rate became the lowest (1.583) when compared to the other countries of our sample.

\section{GDP_per_capita (GDPC)}

This variable is defined as follows: Year Gross Domestic Product is based on purchasing-power parity (PPP) per capita GDP percentage change. In figure 6, for 2007 , Greece recorded a greater percentage change in this variable; in (7.26), contrary to that of the year 2002, a greater percentage change was observed simultaneously 
Table 1. Comparative analysis of QMS document development models

\begin{tabular}{|c|c|c|c|c|c|c|c|c|c|c|c|}
\hline & & Germany & France & $\begin{array}{c}\text { United } \\
\text { Kingdom }\end{array}$ & Belgium & Italy & Netherlands & Luxemburg & Sweden & Denmark & Greece \\
\hline \multicolumn{12}{|c|}{ Inputs } \\
\hline \multirow{2}{*}{$x_{1}$} & Mean & 1556.57 & 10857.59 & 8076.65 & 293.57 & 770.01 & 5206.21 & 880.19 & 2790.32 & 493.25 & 786.48 \\
\hline & SD & 2092.74 & 15094.19 & 13379.97 & 815.42 & 960.19 & 7703.78 & 1278.33 & 3415.19 & 649.03 & 897.59 \\
\hline \multirow{2}{*}{$x_{2}$} & Mean & 652.17 & 2009.13 & 1471.40 & 197.72 & 184.62 & 2242.75 & 247.73 & 618.22 & 73.01 & 258.88 \\
\hline & SD & 835.59 & 2600.15 & 2229.23 & 516.31 & 200.74 & 3305.72 & 322.23 & 702.54 & 83.92 & 268.66 \\
\hline \multirow{2}{*}{$x_{3}$} & Mean & 84395.89 & 126932.2 & 116074.1 & 15051.9 & 9188.17 & 142228.5 & 45138.79 & 63464.41 & 6530.38 & 11909.7 \\
\hline & SD & 88327.55 & 156274.7 & 170359.6 & 40553.8 & 9277.24 & 207420.5 & 57635.76 & 56982.95 & 6382.58 & 12784.6 \\
\hline \multicolumn{12}{|c|}{ Outputs } \\
\hline \multirow{2}{*}{$y_{1}$} & Mean & 18453.67 & 24052.65 & 13322.80 & 2714.15 & 1647.25 & 19956.03 & 15163.28 & 10433.81 & 955.26 & 1548.49 \\
\hline & SD & 20588.23 & 29637.74 & 20329.70 & 7175.72 & 1976.59 & 28865.79 & 19026.03 & 8719.73 & 1151.62 & 1602.70 \\
\hline \multirow{2}{*}{$y_{2}$} & Mean & 39835.54 & 52086.00 & 70056.41 & 6285.02 & 6282.93 & 78187.98 & 14481.94 & 41772.51 & 4342.65 & 7598.66 \\
\hline & SD & 40758.04 & 63138.78 & 102431.5 & 16531.22 & 6403.23 & 115081.35 & 18846.36 & 35266.02 & 4210.97 & 7967.48 \\
\hline \multirow{2}{*}{$y_{3}$} & Mean & 31392.92 & 76248.05 & 31974.88 & 7914.48 & 1346.05 & 47106.32 & 18373.90 & 12627.94 & 1236.64 & 2669.30 \\
\hline & SD & 37500.64 & 106038.3 & 50533.30 & 22506.63 & 1959.53 & 67188.92 & 24520.39 & 15909.86 & 1266.88 & 3303.45 \\
\hline \multicolumn{12}{|c|}{ Macro-economic variables } \\
\hline \multirow{2}{*}{$z_{1}$} & Mean & 1.692 & 1.995 & 1.778 & 1.934 & 2.359 & 2.029 & 2.296 & 1.547 & 1.864 & 3.243 \\
\hline & SD & 0.438 & 0.223 & 0.505 & 0.416 & 0.290 & 0.928 & 0.250 & 0.565 & 0.415 & 0.554 \\
\hline \multirow[b]{2}{*}{$z_{2}$} & Mean & 3.915 & 3.222 & 4.916 & 4.221 & 3.080 & 3.840 & 5.938 & 5.043 & 4.412 & 6.428 \\
\hline & SD & 1.868 & 1.196 & 0.900 & 1.191 & 1.046 & 1.855 & 1.724 & 1.171 & 1.558 & 0.847 \\
\hline
\end{tabular}

Notes: This table reports the mean and the cross-sectional standard deviation (SD) of each variable by country. Notations used in the table are defined as follows: $x_{1}=$ Fixed assets; $x_{2}=$ Labor; $x_{3}=$ Borrowed funds; $y_{1}=$ Interbank loans; $y_{2}=$ Commercial loans; $y_{3}=$ Securities; $z_{1}=$ Inflation rate; $z_{2}=$ GDP per_capita

in Greece and Germany (5.39). However, the smallest percentage change was recorded in the Netherlands and Italy in 2002 and 2007, respectively.

The macroeconomic variables, presented above, allow us to see a considerable economic heterogeneity between European countries. This divergence must influence the technology under which the banks of each country operate. In particular, we expect that these variables have a significant effect on the directional technology gap ratio.

Table 1 summarizes the descriptive statistics of each variable defined above. It presents the means and the standard deviations of the utilized variables. The input and output variables are expressed in millions of Euros, and the macroeconomic variables are expressed in percentages.

\section{Results and Interpretation}

For the purpose of the present study, we were interested in analyzing inter-country differences in the mean efficiency levels of European banking industries and to determine the macroeconomic divergence effect on the banking system efficiency of each country. First, we attempted to define the efficiency levels of European banks based on a common frontier by pooling the data set of all the banks, as well as on separate country-specific technologies for each European banking industry. As a result, we obtained different productive efficiency estimates for each country frontier, the meta-technology and the common technology frontiers of the banking markets (see table 2). The output and input specifications and other variables turned out to be statistically significant for both the meta-technology and common technology models. 
Table 2. Parameter estimation by frontiers and meta-frontier technology

\begin{tabular}{|c|c|c|c|c|c|c|c|c|c|c|c|c|c|}
\hline Var. & Par & Belgium & Denmark & France & Germany & Greece & Italy & Luxemburg & Netherlands & Sweden & $\begin{array}{c}\text { United } \\
\text { Kingdom }\end{array}$ & $\overrightarrow{\mathbf{D}}_{\mathbf{T}^{*}}$ & $\begin{array}{l}\text { Prev. } \\
\text { model }\end{array}$ \\
\hline$c$ & $\alpha_{0}$ & -0.6715 & -0.6957 & 0.0764 & -0.8989 & 0.0755 & 0.5381 & -0.1529 & -0.8855 & 0.4425 & 0.6018 & $\begin{array}{c}0.6954 \\
(0.0310)\end{array}$ & $\begin{array}{c}0.0615 \\
(0.0445)\end{array}$ \\
\hline$x_{1}$ & $\alpha_{1}$ & -0.1442 & $4.42 E-19$ & -0.1851 & -0.1898 & -0.0931 & -0.0854 & -0.0452 & -0.1770 & 0.0000 & -0.2293 & $\begin{array}{l}-0.1238 \\
(0.0033)\end{array}$ & $\begin{array}{c}0.0206 \\
(0.0048)\end{array}$ \\
\hline$x_{2}$ & $\alpha_{2}$ & -0.1596 & $7.51 E-18$ & -0.3010 & -0.1985 & -0.4006 & -0.3467 & -0.3866 & -0.0620 & -0.4501 & -0.1692 & $\begin{array}{c}-0.3463 \\
(0.0088)\end{array}$ & $\begin{array}{c}-0.0784 \\
(0.0046)\end{array}$ \\
\hline$x_{3}$ & $\alpha_{3}$ & -0.1758 & -0.4828 & -0.0022 & -0.1034 & -0.0226 & -0.1237 & -0.0720 & -0.2393 & -0.0938 & -0.1407 & $\begin{array}{l}-0.0930 \\
(0.0013)\end{array}$ & $\begin{array}{c}0.5258 \\
(0.0031)\end{array}$ \\
\hline$y_{1}$ & $\beta_{1}$ & 0.1384 & -0.2701 & 0.0840 & -0.0619 & -0.0243 & -0.0762 & -0.0022 & -0.2162 & 0.0270 & 0.0439 & $\begin{array}{c}0.0891 \\
(0.0027)\end{array}$ & $\begin{array}{l}-0.0821 \\
(0.0058)\end{array}$ \\
\hline$y_{2}$ & $\beta_{2}$ & -0.2060 & 0.1138 & 0.1803 & -0.1424 & 0.0309 & 0.1066 & 0.0128 & 0.1176 & -0.0306 & 0.1260 & $\begin{array}{c}-0.0590 \\
(0.0061)\end{array}$ & $\begin{array}{l}-0.3494 \\
(0.0033)\end{array}$ \\
\hline$y_{3}$ & $\beta_{3}$ & 0.5881 & 0.6736 & 0.2476 & 0.7127 & 0.4771 & 0.4139 & 0.4855 & 0.6203 & 0.4598 & 0.2909 & $\begin{array}{c}0.4068 \\
(0.0124)\end{array}$ & $\begin{array}{l}-0.1005 \\
(0.0092)\end{array}$ \\
\hline$x_{1}^{2}$ & $\alpha_{11}$ & 0.0032 & 0.0075 & -0.0032 & -0.0029 & -0.0115 & -0.0073 & 0.0350 & 0.0137 & 0.0010 & 0.0071 & $\begin{array}{c}0.0188 \\
(0.0015)\end{array}$ & $\begin{array}{l}-0.0021 \\
(0.0006)\end{array}$ \\
\hline$x_{2}^{2}$ & $\alpha_{22}$ & -0.0040 & 0.0061 & -0.0049 & 0.0058 & -0.0303 & -0.0048 & 0.0272 & 0.0197 & -0.0177 & -0.0046 & $\begin{array}{l}0.0062 \\
(0.0013)\end{array}$ & $\begin{array}{l}-0.0013 \\
(0.0025)\end{array}$ \\
\hline$x_{3}^{2}$ & $\alpha_{33}$ & -0.0042 & -0.0335 & -0.0058 & -0.0091 & -0.0002 & 0.0016 & 0.0170 & -0.0379 & 0.0033 & 0.0019 & $\begin{array}{l}-0.0138 \\
(0.0004)\end{array}$ & $\begin{array}{l}-0.0952 \\
(0.0032)\end{array}$ \\
\hline$y_{1}^{2}$ & $\beta_{11}$ & -0.0137 & -0.0146 & -0.0212 & -0.0249 & -0.0167 & -0.0084 & 0.0075 & -0.0210 & -0.0016 & -0.0096 & $\begin{array}{c}0.0079 \\
(0.0014)\end{array}$ & $\begin{array}{c}0.0100 \\
(0.0243)\end{array}$ \\
\hline$y_{2}^{2}$ & $\beta_{22}$ & -0.0231 & -0.0099 & -0.0169 & -0.0110 & -0.0114 & -0.0107 & -0.0354 & -0.0317 & -0.0126 & -0.0385 & $\begin{array}{c}-0.0351 \\
(0.0006)\end{array}$ & $\begin{array}{l}-0.0137 \\
(0.0003)\end{array}$ \\
\hline$y_{3}^{2}$ & $\beta_{33}$ & 0.0378 & 0.0292 & 0.0565 & 0.0448 & 0.0781 & 0.0347 & -0.0849 & 0.0429 & 0.0235 & 0.0402 & $\begin{array}{c}-0.0011 \\
(0.0054)\end{array}$ & $\begin{array}{c}-0.0018 \\
(0.0439)\end{array}$ \\
\hline$x_{1} x_{2}$ & $\alpha_{12}$ & -0.0036 & 0.1150 & 0.0312 & -0.0087 & 0.0423 & 0.0065 & -0.0350 & 0.0216 & 0.0123 & 0.0210 & $\begin{array}{c}0.0014 \\
(0.0002)\end{array}$ & $\begin{array}{c}0.0088 \\
(0.0065)\end{array}$ \\
\hline$x_{1} x_{3}$ & $\alpha_{13}$ & 0.0042 & -0.0616 & -0.0169 & 0.0149 & -0.0031 & 0.0046 & -0.0382 & -0.0128 & 0.0056 & -0.0096 & $\begin{array}{c}-0.0112 \\
(0.0007)\end{array}$ & $\begin{array}{c}0.0046 \\
(0.0133)\end{array}$ \\
\hline$x_{1} y_{1}$ & $\gamma_{11}$ & -0.0050 & 0.0142 & -0.0074 & -0.0103 & -0.0273 & -0.0084 & 0.0563 & -0.0367 & -0.0090 & -0.0053 & $\begin{array}{c}-0.0084 \\
(0.0008)\end{array}$ & $\begin{array}{r}-0.0010 \\
(0.0014)\end{array}$ \\
\hline$x_{1} y_{2}$ & $\gamma_{12}$ & -0.0197 & -0.0948 & -0.0713 & -0.0411 & -0.0701 & -0.0706 & -0.0954 & -0.0204 & -0.0819 & -0.0428 & $\begin{array}{c}-0.0528 \\
(0.0009)\end{array}$ & $\begin{array}{c}-0.0018 \\
(0.0004)\end{array}$ \\
\hline$x_{1} y_{3}$ & $\gamma_{13}$ & 0.0352 & -0.1220 & 0.0383 & 0.0455 & 0.0492 & 0.0668 & 0.1225 & 0.0008 & 0.0806 & 0.0177 & $\begin{array}{c}0.0671 \\
(0.0012)\end{array}$ & $\begin{array}{l}-0.0059 \\
(0.0006)\end{array}$ \\
\hline$x_{2} x_{3}$ & $\alpha_{23}$ & 0.0046 & -0.0332 & -0.0006 & -0.0001 & 0.0027 & -0.0002 & -0.0065 & -0.0048 & -0.0038 & -0.0155 & $\begin{array}{c}0.0003 \\
(0.0007)\end{array}$ & $\begin{array}{c}0.0858 \\
(0.0456)\end{array}$ \\
\hline$x_{2} y_{1}$ & $\gamma_{21}$ & -0.0130 & 0.0311 & 0.0024 & 0.0138 & -0.0007 & -0.0019 & 0.0173 & -0.0504 & 0.0003 & 0.0036 & $\begin{array}{c}-0.0064 \\
(0.0034)\end{array}$ & $\begin{array}{l}-0.0297 \\
(0.0127)\end{array}$ \\
\hline$x_{2} y_{2}$ & $\gamma_{22}$ & -0.0418 & 0.0328 & -0.0048 & -0.0264 & -0.0086 & -0.0197 & -0.0338 & 0.0316 & -0.0020 & -0.0285 & $\begin{array}{c}-0.0141 \\
(0.0008)\end{array}$ & $\begin{array}{c}-0.0543 \\
(0.0039)\end{array}$ \\
\hline$x_{2} y_{3}$ & $\gamma_{23}$ & 0.0435 & 0.1343 & 0.0242 & 0.0095 & 0.0075 & 0.0185 & 0.0454 & 0.0844 & 0.0035 & 0.0635 & $\begin{array}{c}0.0445 \\
(0.0016)\end{array}$ & $\begin{array}{c}-0.0089 \\
(0.0088)\end{array}$ \\
\hline$x_{3} y_{1}$ & $\gamma_{31}$ & 0.0041 & -0.0090 & 0.0060 & 0.0000 & -0.0053 & -0.0095 & -0.0064 & 0.0174 & -0.0002 & -0.0026 & $\begin{array}{c}0.0013 \\
(0.0065)\end{array}$ & $\begin{array}{c}-0.0036 \\
(0.0133)\end{array}$ \\
\hline$x_{3} y_{2}$ & $\gamma_{32}$ & 0.0153 & -0.0077 & 0.0030 & -0.0022 & 0.0019 & 0.0033 & 0.0215 & -0.0395 & -0.0008 & 0.0148 & $\begin{array}{c}0.0019 \\
(0.0005)\end{array}$ & $\begin{array}{c}0.0769 \\
(0.0003)\end{array}$ \\
\hline$x_{3} y_{3}$ & $\gamma_{33}$ & 0.0022 & 0.0075 & 0.0077 & 0.0249 & 0.0506 & 0.0344 & -0.0798 & 0.1163 & 0.0096 & 0.0007 & $\begin{array}{c}-0.0021 \\
(0.0004)\end{array}$ & $\begin{array}{c}0.0289 \\
(0.0022)\end{array}$ \\
\hline$y_{1} y_{2}$ & $\beta_{12}$ & 0.0105 & 0.0279 & 0.0371 & -0.0045 & -0.0001 & -0.0182 & -0.0159 & 0.0214 & -0.0004 & 0.0045 & $\begin{array}{c}0.0202 \\
(0.0006)\end{array}$ & $\begin{array}{l}0.0159 \\
(0.0013)\end{array}$ \\
\hline$y_{1} y_{3}$ & $\beta_{13}$ & 0.0682 & 0.0293 & 0.0195 & 0.0895 & 0.0817 & 0.1113 & 0.1571 & 0.0102 & 0.0966 & 0.0753 & $\begin{array}{l}0.06 / 5 \\
(0.0014)\end{array}$ & $\begin{array}{l}-0.0039 \\
(0.0005)\end{array}$ \\
\hline$y_{2} y_{3}$ & $\beta_{23}$ & -0.1002 & -0.0476 & -0.0736 & -0.1078 & -0.1289 & -0.1210 & -0.0771 & -0.1263 & -0.1039 & -0.0922 & $\begin{array}{l}-0.0870 \\
(0.0012)\end{array}$ & $\begin{array}{l}-0.0058 \\
(0.0005)\end{array}$ \\
\hline$t$ & $\delta_{1}$ & -0.0232 & -0.0003 & 0.0160 & -0.0051 & 0.0243 & 0.0129 & -0.0132 & 0.0095 & 0.0276 & 0.0060 & $\begin{array}{c}0.0727 \\
(0.0020)\end{array}$ & $\begin{array}{c}0.0013 \\
(0.0203)\end{array}$ \\
\hline$t^{2}$ & $\delta_{2}$ & -0.0003 & 0.0027 & -0.0008 & 0.0010 & -0.0002 & 0.0004 & 0.0048 & -0.0005 & -0.0013 & 0.0020 & $\begin{array}{c}0.0006 \\
(0.0149)\end{array}$ & $\begin{array}{l}-0.0006 \\
(0.0338)\end{array}$ \\
\hline$t x_{1}$ & $\psi_{1}$ & 0.0009 & 0.0049 & -0.0009 & 0.0025 & 0.0007 & 0.0012 & 0.0010 & -0.0016 & -0.0015 & -0.0035 & $\begin{array}{c}0.0031 \\
(0.0032)\end{array}$ & $\begin{array}{l}-0.0032 \\
(0.0121)\end{array}$ \\
\hline$t x_{2}$ & $\psi_{2}$ & -0.0013 & 0.0057 & -0.0010 & 0.0010 & -0.0010 & -0.0015 & -0.0043 & 0.0011 & -0.0016 & 0.0061 & $\begin{array}{l}-0.0009 \\
(0.0021)\end{array}$ & $\begin{array}{c}0.0022 \\
(0.0051)\end{array}$ \\
\hline$t x_{3}$ & $\psi_{3}$ & 0.0010 & -0.0096 & 0.0015 & -0.0031 & 0.0001 & -0.0002 & 0.0034 & 0.0006 & 0.0026 & -0.0034 & $\begin{array}{c}-0.0038 \\
(0.0023)\end{array}$ & $\begin{array}{c}0.0009 \\
(0.0014)\end{array}$ \\
\hline$t y_{1}$ & $\eta_{1}$ & -0.0015 & 0.0043 & 0.0010 & -0.0013 & 0.0018 & -0.0016 & 0.0002 & -0.0056 & -0.0016 & 0.0000 & $\begin{array}{c}0.0016 \\
(0.0016)\end{array}$ & $\begin{array}{c}0.0014 \\
(0.0045)\end{array}$ \\
\hline$t y_{2}$ & $\eta_{2}$ & -0.0008 & 0.0044 & -0.0014 & 0.0031 & 0.0023 & 0.0006 & 0.0007 & 0.0084 & 0.0011 & -0.0010 & $\begin{array}{c}0.0033 \\
(0.0016)\end{array}$ & $\begin{array}{l}0.00005 \\
(0.0034)\end{array}$ \\
\hline$t y_{3}$ & $\eta_{3}$ & 0.0028 & -0.0078 & 0.0000 & -0.0014 & -0.0044 & 0.0005 & -0.0008 & -0.0027 & 0.0000 & 0.0001 & $\begin{array}{c}-0.0065 \\
(0.0007) \\
\end{array}$ & $\begin{array}{l}-0.0015 \\
(0.0019) \\
\end{array}$ \\
\hline
\end{tabular}

Notes: Different notations used in this table are defined as follows: $x_{1}=$ Fixed assets; $x_{2}=$ Labor; $x_{3}=$ Borrowed funds; $y_{1}=$ Interbank loans; $y_{2}=$ Commercial loans; $y_{3}=$ Securities; $t=$ trend time variable that explains technical progress. 
Table 3. Efficiency estimate by country

\begin{tabular}{|c|c|c|c|c|c|c|c|c|c|c|c|}
\hline & & Belgium & Denmark & France & Germany & Greece & Italy & Luxemburg & Netherlands & Sweden & $\begin{array}{l}\text { United } \\
\text { Kingdom }\end{array}$ \\
\hline & \multicolumn{11}{|c|}{2002} \\
\hline Model 1 & & 0,2597 & 0,1734 & 0,3661 & 0,2706 & 0,1635 & 0,3236 & 0,2421 & 0,1385 & 0,2550 & 0,2697 \\
\hline \multirow{3}{*}{ Model 2} & $\overrightarrow{\mathbf{D}}_{T^{k}}$ & 0,1799 & 0,1754 & 0,1955 & 0,1477 & 0,1510 & 0,2223 & 0,1684 & 0,1265 & 0,2515 & 0,1991 \\
\hline & $\overrightarrow{\mathbf{D}}_{\mathrm{T}^{*}}^{*}$ & 0,2156 & 0,2157 & 0,2648 & 0,1579 & 0,1836 & 0,2589 & 0,1924 & 0,1564 & 0,2754 & 0,2222 \\
\hline & \multicolumn{11}{|c|}{2003} \\
\hline Model 1 & & 0,3507 & 0,1697 & 0,2692 & 0,3011 & 0,1629 & 0,2870 & 0,3397 & 0,1428 & 0,1881 & 0,3124 \\
\hline \multirow{3}{*}{ Model 2} & $\overrightarrow{\mathbf{D}}_{T^{k}}$ & 0,1864 & 0,1879 & 0,1947 & 0,1721 & 0,1785 & 0,1845 & 0,2666 & 0,2315 & 0,1996 & 0,2576 \\
\hline & $\overrightarrow{\mathbf{D}}_{\mathrm{T}^{*}}$ & 0,2469 & 0,2546 & 0,2143 & 0,1925 & 0,1948 & 0,2512 & 0,2875 & 0,2644 & 0,2156 & 0,2929 \\
\hline & \multicolumn{11}{|c|}{2004} \\
\hline Model 1 & & 0,3449 & 0,1357 & 0,2645 & 0,2813 & 0,1592 & 0,2295 & 0,3429 & 0,2526 & 0,2907 & 0,2617 \\
\hline \multirow{3}{*}{ Model 2} & $\overrightarrow{\mathbf{D}}_{T^{k}}$ & 0,2154 & 0,2548 & 0,2211 & 0,1988 & 0,1679 & 0,1962 & 0,2532 & 0,2584 & 0,2756 & 0,2394 \\
\hline & $\overrightarrow{\mathbf{D}}_{\mathrm{T}^{*}}$ & 0,2234 & 0,2977 & 0,2412 & 0,2164 & 0,1865 & 0,2159 & 0,2845 & 0,2695 & 0,3003 & 0,2485 \\
\hline & \multicolumn{11}{|c|}{2005} \\
\hline Model 1 & & 0,2539 & 0,1510 & 0,2703 & 0,4095 & 0,3239 & 0,3094 & 0,3808 & 0,2847 & 0,2613 & 0,3969 \\
\hline \multirow{3}{*}{ Model 2} & $\overrightarrow{\mathbf{D}}_{\mathrm{T}^{\mathrm{k}}}$ & 0,2143 & 0,1945 & 0,2289 & 0,1842 & 0,2964 & 0,2005 & 0,2326 & 0,2755 & 0,2135 & 0,2248 \\
\hline & $\overrightarrow{\mathbf{D}}_{\mathrm{T}}^{*}$ & 0,2314 & 0,2514 & 0,2378 & 0,2151 & 0,3333 & 0,2456 & 0,2784 & 0,2994 & 0,2488 & 0,2315 \\
\hline & \multicolumn{11}{|c|}{2006} \\
\hline Model 1 & & 0,2242 & 0,1394 & 0,2814 & 0,3326 & 0,1702 & 0,2674 & 0,4327 & 0,1749 & 0,3926 & 0,3296 \\
\hline \multirow{3}{*}{ Model 2} & $\overrightarrow{\mathbf{D}}_{T^{k}}$ & 0,1738 & 0,2165 & 0,2187 & 0,1964 & 0,2136 & 0,1743 & 0,2598 & 0,1555 & 0,2544 & 0,2376 \\
\hline & $\overline{\mathbf{D}}_{\mathrm{T}}^{*}$ & 0,1954 & 0,2549 & 0,2333 & 0,2132 & 0,2288 & 0,1947 & 0,2797 & 0,1678 & 0,2711 & 0,2541 \\
\hline & \multicolumn{11}{|c|}{2007} \\
\hline Model 1 & & 0,3073 & 0,1468 & 0,2468 & 0,2723 & 0,1734 & 0,2337 & 0,3918 & 0,1758 & 0,3832 & 0,3260 \\
\hline \multirow{3}{*}{ Model 2} & $\overrightarrow{\mathbf{D}}_{T^{k}}$ & 0,2235 & 0,2564 & 0,2076 & 0,1764 & 0,2144 & 0,1856 & 0,2479 & 0,1598 & 0,2487 & 0,2376 \\
\hline & $\overrightarrow{\mathbf{D}}_{\mathrm{T}^{*}}^{*}$ & 0,2459 & 0,2945 & 0,2314 & 0,1987 & 0,2266 & 0,2007 & 0,2689 & 0,1625 & 0,2525 & 0,2544 \\
\hline & \multicolumn{11}{|c|}{ 2002-2007 } \\
\hline Model 1 & & 0,2901 & 0,1527 & 0,2831 & 0,3112 & 0,1922 & 0,2751 & 0,3550 & 0,1949 & 0,2952 & 0,3161 \\
\hline \multirow{2}{*}{ Model 2} & $\overrightarrow{\mathbf{D}}_{\mathrm{T}^{\mathbf{k}}}$ & 0,1989 & 0,2143 & 0,2111 & 0,1793 & 0,2036 & 0,1939 & 0,2381 & 0,2012 & 0,2406 & 0,2327 \\
\hline & $\overrightarrow{\mathbf{D}}_{\mathrm{T}^{*}}$ & 0,2264 & 0,2615 & 0,2371 & 0,1990 & 0,2256 & 0,2278 & 0,2652 & 0,2200 & 0,2606 & 0,2506 \\
\hline
\end{tabular}

Notes: This table reports a comparison of the average annual inefficiency scores estimated by model 1 and model 2 for each country reported by year and for the whole period. Model 1 is the common technology frontier. In model 2, the inefficiency scores are assessed first, referring to the country-specific technology frontier $\overrightarrow{\mathbf{D}}_{\mathbf{T}^{\mathbf{k}}}$. In a second stage we assess the inefficiency scores referring to the meta-technology frontier $\overrightarrow{\mathbf{D}}_{\mathbf{T}}$ *

Usually, most studies estimate a common technology frontier without taking into account the different factors that can influence the various markets. These approaches did not allow us to adequately compare efficiency levels across countries. However, the metatechnology approach allowed us to properly compare technical efficiency levels and to determine potential differences between countries.
Table 2 reports the estimated parameters for country-specific technology. The last two columns of this table list the estimated parameters of the meta-technology and the common technology, respectively, using parametric linear programming. Standard errors attached to these frontiers were obtained through a parametric bootstrapping method. Treating the sample as if it were the population, we randomly drew re- 

Table 4. The directional technology gap ratio by country

\begin{tabular}{|c|c|c|c|c|c|c|c|c|c|c|}
\hline & Belgium & Denmark & France & Germany & Greece & Italy & Luxemburg & Netherlands & Sweden & $\begin{array}{c}\text { United } \\
\text { Kingdom }\end{array}$ \\
\hline \multicolumn{11}{|c|}{2002} \\
\hline$D T E^{k}$ & 0,1799 & 0,1477 & 0,1955 & 0,1754 & 0,1510 & 0,2223 & 0,1684 & 0,1265 & 0,2515 & 0,1991 \\
\hline$D T E^{*}$ & 0,2156 & 0,1579 & 0,2648 & 0,2157 & 0,1836 & 0,2589 & 0,1924 & 0,1564 & 0,2754 & 0,2222 \\
\hline$D T G R^{k}$ & 1,1984 & 1,0691 & 1,3545 & 1,2298 & 1,2159 & 1,1646 & 1,1425 & 1,2364 & 1,0950 & 1,1160 \\
\hline \multicolumn{11}{|c|}{2003} \\
\hline$D T E^{k}$ & 0,1864 & 0,1721 & 0,1947 & 0,1879 & 0,1785 & 0,1845 & 0,2666 & 0,2315 & 0,1996 & 0,2576 \\
\hline$D T E^{*}$ & 0,2469 & 0,1925 & 0,2143 & 0,2546 & 0,1948 & 0,2512 & 0,2875 & 0,2644 & 0,2156 & 0,2929 \\
\hline$D T G R^{k}$ & 1,3246 & 1,1185 & 1,1007 & 1,3550 & 1,0913 & 1,3615 & 1,0784 & 1,1421 & 1,0802 & 1,1370 \\
\hline \multicolumn{11}{|c|}{2004} \\
\hline$D T E^{k}$ & 0,2154 & 0,1988 & 0,2211 & 0,2548 & 0,1679 & 0,1962 & 0,2532 & 0,2584 & 0,2756 & 0,2394 \\
\hline$D T E^{*}$ & 0,2234 & 0,2164 & 0,2412 & 0,2977 & 0,1865 & 0,2159 & 0,2845 & 0,2695 & 0,3003 & 0,2485 \\
\hline$D T G R^{k}$ & 1,0371 & 1,0885 & 1,0909 & 1,1684 & 1,1108 & 1,1004 & 1,1236 & 1,0430 & 1,0896 & 1,0380 \\
\hline \multicolumn{11}{|c|}{2005} \\
\hline$D T E^{k}$ & 0,2143 & 0,1842 & 0,2289 & 0,1945 & 0,2964 & 0,2005 & 0,2326 & 0,2755 & 0,2135 & 0,2248 \\
\hline$D T E^{*}$ & 0,2314 & 0,2151 & 0,2378 & 0,2514 & 0,3333 & 0,2456 & 0,2784 & 0,2994 & 0,2488 & 0,2315 \\
\hline$D T G R^{k}$ & 1,0798 & 1,1678 & 1,0389 & 1,2925 & 1,1245 & 1,2249 & 1,1969 & 1,0868 & 1,1653 & 1,0298 \\
\hline \multicolumn{11}{|c|}{2006} \\
\hline$D T E^{k}$ & 0,1738 & 0,1964 & 0,2187 & 0,2165 & 0,2136 & 0,1743 & 0,2598 & 0,1555 & 0,2544 & 0,2376 \\
\hline$D T E^{*}$ & 0,1954 & 0,2132 & 0,2333 & 0,2549 & 0,2288 & 0,1947 & 0,2797 & 0,1678 & 0,2711 & 0,2541 \\
\hline$D T G R^{k}$ & 1,1243 & 1,0855 & 1,0668 & 1,1774 & 1,0712 & 1,1170 & 1,0766 & 1,0791 & 1,0656 & 1,0694 \\
\hline \multicolumn{11}{|c|}{2007} \\
\hline$D T E^{k}$ & 0,2235 & 0,1764 & 0,2076 & 0,2564 & 0,2144 & 0,1856 & 0,2479 & 0,1598 & 0,2487 & 0,2376 \\
\hline$D T E^{*}$ & 0,2459 & 0,1987 & 0,2314 & 0,2945 & 0,2266 & 0,2007 & 0,2689 & 0,1625 & 0,2525 & 0,2544 \\
\hline$D T G R^{k}$ & 1,1002 & 1,1264 & 1,1146 & 1,1486 & 1,0569 & 1,0814 & 1,0847 & 1,0169 & 1,0153 & 1,0707 \\
\hline \multicolumn{11}{|c|}{$2002-2007$} \\
\hline$D T E^{k}$ & 0,1989 & 0,1793 & 0,2111 & 0,2143 & 0,2036 & 0,1939 & 0,2381 & 0,2012 & 0,2406 & 0,2327 \\
\hline$D T E^{*}$ & 0,2264 & 0,1990 & 0,2371 & 0,2615 & 0,2256 & 0,2278 & 0,2652 & 0,2200 & 0,2606 & 0,2506 \\
\hline$D T G R^{k}$ & 1,1383 & 1,1099 & 1,1232 & 1,2203 & 1,1081 & 1,1748 & 1,1138 & 1,0934 & 1,0831 & 1,0769 \\
\hline
\end{tabular}

Notes: Different notations used in this table are defined as follows: $\boldsymbol{D T E}{ }^{\boldsymbol{k}}$ : the directional technical efficiency for country k

$\boldsymbol{D T E}^{*}$ : the directional technical efficiency assessed from the meta-technology; $\boldsymbol{D T G R}{ }^{\boldsymbol{k}}$ : directional technology gap ratio for country $k$.

levels, respectively. In addition, the adjusted R-squared value is 0.7864 , indicating that the macroeconomics variables which we utilized in our regression can explain $78.64 \%$ of the deviation of the directional technology gap ratio.

These econometric results support important economic interpretations. On the one hand, a high rate of inflation weakens the real interest rate and can in- duce a negative real rate if the inflation rate exceeds the nominal interest rate fixed by the central bank. A similar situation causes bank bankruptcies and consequently triggers economic crises. On the other hand, the more one improves the GDP per capita, the more the banking system is developed. Improvement of household incomes increases savings, which enhances banks' inputs; thus, their outputs and 
Table 5. Macroeconomic effect on the directional technology gap ratio

\begin{tabular}{|c|c|c|c|c|}
\hline variables & & Coefficients & t-ratio & Probability \\
\hline INFR & & -0.0030341 & -2.3505 & 0.0238 \\
\hline GDPC & & 0.0046149 & 3.4468 & 0.0013 \\
\hline \multicolumn{5}{|c|}{ Fixed Effects } \\
\hline$B L$ & 0.017870 & & & \\
\hline DN & 0.013012 & & & \\
\hline FR & 0.112278 & & & \\
\hline GE & 0.179451 & & & \\
\hline GR & 0.041328 & & & \\
\hline IT & 0.222131 & & & \\
\hline$L X$ & 0.244606 & & & \\
\hline $\mathrm{NL}$ & 0.051173 & & & \\
\hline SD & 0.045585 & & & \\
\hline UK & 0.124611 & & & \\
\hline R-squared & & 0.8351 & & \\
\hline Adjusted R-squared & & 0.7864 & & \\
\hline Prob.(F-statistic) & & 0.000000 & & \\
\hline
\end{tabular}

turnovers will increase. Finally, the development of specific country's banks' technology is influenced by monetary and budgetary policies and the environmental features of this country.

\section{Conclusion}

Despite the construction of the European Central Bank and the creation of the European Monetary Union, the development divergence between European nations is a reality that we cannot hide. From this starting point, we observe that each country has its specific economic features. These features influence the development of each country's banking sector significantly. In fact, the technology under which the banks of a particular country operate is not the same as that of the other countries. For this reason, to study inter-country bank efficiency, it is necessary to model the specific technology for each country. Once this is achieved, we can construct an envelope technology that includes all the country-specific technologies.

Our results show first that the estimated parameters of the meta-technology frontier are more significant than those of the common technology frontier. Second, we found a significant divergence in the results between the two frontiers; the countries' rankings have changed, and most inefficiency scores are underestimated in the meta-technology approach.
Third, in assessing the directional technology gap ratio, we discovered that the German banking system is technologically the least developed, whereas the United Kingdom banking system is technologically the most developed one compared to the other banking systems in our sample. Finally, the regression of this ratio on the macro-economic indicators indicates significant influence of the inflation rate and the GDP per capita. Therefore, our concluding remark regarding these regression results is that each country must minimize its inflation rate and increase its GDP per capita to ensure the technological development of its banking system and avoid possible economic crises.

\section{References}

Aigner, D. J., \& Chu, S. J. (1968). On estimating the industry production function. American Economic Review, 58 (4), 826-839.

Allen, L., \& Rai, A. (1996). Operational Efficiency in Banking: An International Comparison. Journal of Banking and Finance, 20 (4), 655-672.

Battese, G. E., \& Rao, D. S. P. (2002). Technology Gap, Efficiency and a Stochastic Metafrontier Function. International Journal of Business and Economics, 1 (2), 1-7. 
Battese, G. E., Rao, D. S. P., \& O’Donnell, C. J. (2004). A Metafrontier Production Function for Estimation of Technical Efficiencies and Technology Gaps for Firms Operating Under Different Technologies. Journal of Productivity Analysis, 21 (1), 91-103.

Berg, S., Førsund, F., Hjalmarsson, L., \& Suominen, M. (1993). Banking efficiency in the Nordic countries. Journal of Banking and Finance, 17 (2-3), 371-388.

Berg, S., Førsund, F., \& Jansen, E. (1992). Malmquist indices of productivity growth during the deregulation of Norwegian banking 1980-89. Scandinavian Journal of Economics, 94 (Suppl.), 211-228.

Berger, A. N., Bonime, S. D., Covitz, D. M., \& Hancock, D. (2000). Why Are Bank Profits So Persistent? The Roles of Product Market Competition, Informational Opacity, and Regional/Macroeconomic Shocks. Journal of Banking and Finance, 24 (7), 1203-1235.

Berger, A. N., \& Humphrey, D. B. (1991). The dominance of inefficiencies over scale and product mix economies in banking. Journal of Monetary Economics, 28 (1), 117-148.

Berger, A. N., \& Humphrey, D. B. (1992). Measurement and Efficiency Issues in Commercial Banking. In Z. Griliches (Ed.), Output Measurement in the Service Sectors (pp. 245-300). Chicago, IL: University of Chicago Press.

Berger, A. N., \& Mester, L. J. (1997). Inside the black box: What explains differences in the efficiencies of financial institutions. Journal of Banking and Finance, 21 (7), 895-947.

Bikker, J. A. (2002). Efficiency and Cost Differences across Countries in a Unified European Banking Market (Staff Report No. 87). Amsterdam: Netherlands Central Bank, Directorate Supervision. Retrieved from http://www.dnb.nl/binaries/ sr087_tcm46-146864.pdf

Bos, J. W. B., \& Kolari, J. W. (2005). Large bank efficiency in Europe and the United States: Are there economic motivations for geographic expansion in financial services? Journal of Business, 78 (4), 1555-1592.

Bos, J. W. B., \& Schmiedel, H. (2007). Is there a single frontier in a single European banking market?. Journal of Banking and Finance, 31 (7), 2081-2102.
Bottasso, A., \& Sembenelli, A. (2004). Does ownership affect firms' efficiency? Panel data evidence on Italy. Empirical Economics, 29 (4), 769-786.

Boyd, J. H., Levine, R., \& Smith, B. D. (2001). The impact of inflation on financial sector performance. Journal of Monetary Economics, 47 (2), 221-248.

Chaffai, M. E., Dietsch, M., \& Lozano-Vivas, A. (2001). Technological and environmental differences in the European banking industries. Journal of Financial Services Research, 19 (2-3), 147-162.

Chambers, R. G., Chung, Y. H., \& Färe, R. (1996). Benefit and distance functions. Journal of Economic Theory, 70 (2), 407-419.

Chang, C. E., Hasan, I., \& Hunter, W. C. (1998). Efficiency of multinational banks. An empirical investigation. Applied Financial Economics, 8 (6), 689-696

Demirguc-Kunt, A., Laeven, L., \& Levine, R. (2004). Regulations, market structure, institutions, and the cost of financial intermediation. Journal of Money, Credit and Banking, 36 (3), 593-622.

DeYoung, R., \& Nolle, D. E. (1996). Foreign-owned banks in the US: Earning market share or buying it? Journal of Money, Credit and Banking, 28 (4), 622-636

Dietsch, M., \& Lozano-Vivas, A. (2000). How the Environment Determines Banking Efficiency: A Comparison between French and Spanish Industries. Journal of Banking and Finance, 24 (6), 985-1004.

Färe, R., Grosskopf, S., Noh, D. W., \& Weber, W. (2005). Characteristics of a polluting technology: theory and practice. Journal of Econometrics, 126 (2), 469-492.

Fukuyama, H., \& Weber, W. L. (2008). Japanese banking inefficiency and shadow pricing. Mathematical and Computer Modelling, 48 (11-12), 1854-1867.

Hachicha, N., \& Jarraya, B. (2010). Corporate Governance Productivity Index In Banking Industry: Evidence from The European Banking Industry. Banking and Finance Review, 2 (1), 37-56.

Hauner, D. (2005). Explaining efficiency differences among large German and Austrian banks. Applied Economics, 37 (9), 969-980.

Hayami, Y., \& Ruttan, V. W. (1971). Agricultural Development: An International Perspective. Baltimore, MD: Johns Hopkins University Press. 
Jackowicz, K., \& Kowalewski, O. (2011). Divestments in Banking. Preliminary Evidence on the Role of External Factors. Contemporary Economics, 5 (2), 30-41.

Jackowicz, K., Kowalewski, O., \& Kozłowski, Ł. (2011). The Short and Long Term Performance Persistence in the Central European Banking Industry. Contemporary Economics, 5 (4), 18-31.

Jarraya, B., \& Bouri, A. (2013). MultiObjective Optimization for Asset Allocation in European NonLife Insurance Companies. Journal of Multi-Criteria Decision Analysis, 20 (3-4), 97-108.

Kasman, A., \& Yildirim, C. (2006). Cost and profit efficiencies in transition banking: the case of new EU members. Applied Economics, 38 (9), 1079-1090.

Khan, M. S., \& Senhadji, A. S., (2000). Financial development and economic growth: an overview (Working Paper No. 209). International Monetary Fund.

Kontolaimou, A., \& Tsekouras, K. (2010). Are the Cooperatives the weakest link in European Banking? A Non-parametric Metafrontier Approach. Journal of Banking and Finance, 34 (8), 1946-1957.

Leibenstein, H. (1966). Allocative Efficiency versus X-efficiency. American Economic Review, 56 (3), 392-415.

Lozano-Vivas, A., Pastor, J. T., \& Hasan, I. (2001). European bank performance beyond country borders: What really matters? European Finance Review, 5 (1-2), 141-165.

Lozano-Vivas, V., Pastor, J. T., \& Pastor, J. M. (2002). An efficiency comparison of European banking systems operating under different environmental conditions. Journal of Productivity Analysis, 18 (1), 59-77.

Mahajan, A., Rangan, N., \& Zardkoohi, A. (1996). Cost structures in multinational and domestic banking. Journal of Banking and Finance, 20 (2), 238-306.

Maudos, J., Pastor, J. M., Perez, F., \& Quesada, J. (2002). Cost and profit efficiency in European banks. Journal of International Financial Markets, Institution and Money, 12 (1), 33-58.

McAllister, P. H., \& McManus, D. (1993). Resolving the scale efficiency puzzle in banking. Journal of Banking and Finance, 17 (2-3), 389-405.

Mester, L. J. (1996). A study of bank efficiency taking into account risk-preferences. Journal of Banking and Finance, 20 (6), 1025-1045.
O’Donnell, C. J., Rao, D. S. P., \& Battese, G. E. (2008). Metafrontier frameworks for the study of firmlevel efficiencies and technology ratios. Empirical Economics, 34 (2), 231-255.

Oh, D. H., Lee, J. D. (2010). A metafrontier approach for measuring Malmquist productivity index. Empirical Economics, 38 (1), 47-64.

Orea, L., \& Kumbhakar, S. C. (2004). Efficiency measurement using a latent class stochastic frontier model. Empirical Economics, 29 (1), 169-183.

Qinyu, W., Johnson, J. K., Berger, A. N., \& DeYoung, R. (1997). Problem loans and cost efficiency in commercial banks. Journal of Banking and Finance, 21 (6), 849-870.

Pasiouras, F. (2008). International evidence on the impact of regulations and supervision on banks' technical efficiency: an application of two-stage data envelopment analysis. Review of Quantitative Finance and Accounting, 30 (2), 187-223.

Pastor, J. M., Pérez, F., \& Quesada, J. (1997). Efficiency Analysis in Banking Firms: An International Comparison. European Journal of Operational Research, 98 (2), 395-407.

Pastor, J. M., \& Serrano, L. (2005). Efficiency, endogenous and exogenous credit risk in the banking systems of the Euro area. Applied Financial Economics, 15 (9), 631-649.

Peek, J., Rosengren, E. S., \& Kasirye, F. (1999). The poor performance of foreign bank subsidiaries: Were the problems acquired or created? Journal of Banking and Finance, 23 (2), 579-604.

Sealey, C. W., \& Lindley, J. T. (1977). Inputs, outputs and a theory of production and cost at depository financial institutions. Journal of Finance, 32 (4), 1251-1266.

Stefański, M. (2009). Transformation of the Polish Banking Sector. Contemporary Economics, 3 (3), 37-54.

Vander Vennet, R. (1994). Concentration, efficiency and entry barriers as determinants for EC bank profitability. Journal of International Financial Markets, Institutions, and Money, 4 (3-4), 21-46.

Yildirim, H.S., Philippatos, G. C. (2007). Competition and Contestability in Central and Eastern European Banking Industry. Managerial Finance,33 (3), 195-209.

Zago, A., \& Dongili, P. (2011). Credit quality and technical efficiency in banking. Empirical Economics, 40 (2), 537-558. 
